\title{
Tænketankes brug af dagbladene som et marked for politiske idéer i Danmark
}

\author{
Jesper Dahl Kelstrup
}

Indledning

Tænketanke er i de seneste ti år blevet en etableret bestanddel af den politiske debat i Danmark. Den stigende tendens til at tænketanke tilkæmper sig spalteplads har bl.a. manifesteret sig ved at Dagbladet Børsen i december 2014, for tredje år i træk, kårede Mads Lundby fra den borgerligtliberale tænketank Cepos, som den mest citerede økonom i Danmark (Henriksen, 2014). Denne artikel spørger, hvordan danske tænketankes synlighed i landsdækkende dagblade har udviklet sig sammenlignet med interesseorganisationer i de sidste ti år og hvad der kan forklare denne udvikling? Artiklen falder i to dele. I første del defineres tænketanke som "permanente organisationer, der hævder en grad af uafhængighed og søger politisk indflydelse ved at mobilisere ekspertviden" (Kelstrup, 2014, 21). Som baggrund for definitionen skitseres tænketankes etablering i efterkrigstidens USA, herunder den forestilling om uafhængighed, der har været med til at legitimere tænketankes ekspertviden. Desuden fremstilles den kritik som tænketanke i stigende grad fra 1990erne har været udsat for. Særligt er tænketankes sammenblanding af ekspertise og politiske interesser blevet kritiseret (Rich, 2004).

I anden del uddybes det, hvad der kan forklare, at tænketanke har vundet indpas i danske dagblade i det seneste årti på trods af den stigende kritik af disse organisationer i den internationale litteratur og det aftagende antal af nye tænketanke globalt. Der tegnes et analytisk billede af det relative styrkeforhold imellem gruppen af de mest citerede tænketanke og interesseorganisationer i perioden fra 1. januar 2006 til 31. december 2015. For at forstå fremvæksten af tænketanke anskues dagbladene som et marked, hvor tænketanke kan bruge deres (påståede) uafhængighed til at præsentere og at få anerkendt idéer, som andre aktører efterspørger. Forestillingen knytter an til teorier om agendasetting og blame avoidance. Desuden undersøges udviklingen i citationer for hver af de ti mest aktive tænketanke i dagbladene med henblik på at anskueliggøre forskelle i forskellige tænketankes synlighed. Analysen indikerer, at tænketanke med tydelige idépolitiske udgangspunkter får mere omtale i de landsdækkende dagblade end tænketanke, der er mere fokuseret på bestemte policyområder eller temaer. Det konkluderes, at den øgede synlighed af tænketanke i landsdækkende 
dagblade er et vigtigt udgangspunkt for at belyse årsager til og konsekvenser af deres fremvækst $\mathrm{i}$ Danmark, herunder hvad fremvæksten af et øget antal tænketanke betyder for disse organisationers rolle $\mathrm{i}$ fremtiden.

\section{Tænketankes fremvækst i USA og etablering i Danmark}

Forståelsen og definitioner af tænketanke afspejler, at tænketanksbegrebet stammer fra USA. Tænketanke er her vokset ud af en liberal tradition for pluralisme, vægt på filantropi og billigelse af privatfinansierede aktørers rolle i den politiske proces (Abelson, 2006, 43; Dickson, 1972). Nedenfor defineres tænketanksbegrebet, og det uddybes hvordan forståelsen af tænketanke har udviklet sig og siden mødt kritik i den amerikanske kontekst.

\section{Hvad er en tænketank?}

En vigtig udfordring i definitionen af tænketanke er at balancere imellem, hvad der er nødvendige og tilstrækkelige betingelser for at bruge begrebet (Sartori, 1970, 1044). Det er på den ene side nødvendigt med en præcis definition, der adskiller tænketanke fra beslægtede organisationer som universiteter, interesseorganisationer og konsulentvirksomheder, hvis tænketanke skal etableres som et selvstændigt begreb og ikke blot ses som en undertype af fx interesseorganisationer. På den anden side må definitionen, i hvert fald hvis den skal anvendes komparativt, være bred nok til at omfatte tænketanke fra forskellige politiske systemer. I en dansk og kontinental-europæisk kontekst, hvor der er tradition for offentlig finansiering af tænketanke, er den amerikanske forståelse af tænketanke som private organisationer for snæver. For også at inkludere offentligt finansierede tænketanke, defineres tænketanke her bredt som "permanente organisationer, der hævder en grad af uafhængighed og søger politisk indflydelse ved at mobilisere ekspertviden" (Kelstrup, 2014, 21).

Der er tre nøglebegreber i denne definition. For det første anses tænketanke for at være permanente. Dermed er projektgrupper og kommissioner, der bliver nedsat som "tænketanke" til at løse et konkret politisk problem undtaget fra definitionen. For det andet hævder tænketanke en grad af uafhængighed. Som vi vender tilbage til i diskussionen af tænketankes historik nedenfor, er tænketankes uafhængighed et omdiskuteret, men ikke desto mindre et nødvendigt kriterium, fordi en vigtig kilde til tænketankes legitimitet ligger i deres afstand til etablerede interesser. For det tredje søger tænketanke politisk indflydelse ved at mobilisere ekspertviden. Selvom tænketanke kan udføre meget 
forskellige funktioner bl.a. knyttet til politisk uddannelse af meningsdannere eller konferencer med erhvervslivet, er det nødvendigt for alle tænketanke at orientere sig imod politisk indflydelse, dvs. i retning af politikere og centrale meningsdannere, der er medbestemmende for hvordan politik aftales og reguleres. Medierne, herunder landsdækkende dagblade, er som det fremgår nedenfor en vigtig arena for denne mobilisering af ekspertviden.

Tænketankes styrke ligger således i at mobilisere ekspertviden, der ofte bygger på et evidensgrundlag. Hensigten er, at tænketankes påståede uafhængighed i kombination med deres ekspertise kan bidrage til, at deres analyser og idéer bliver anerkendt i en politisk offentlighed (Arnoldi, 2005). Definitionen kræver ikke, at tænketankes analyser (som universiteternes forskning) lever op til videnskabelige konventioner ved $\mathrm{fx}$ at publicere deres viden i fagfællebedømte tidsskrifter. For tænketanke er formålet netop, til forskel fra universiteter, at få analyser og idéer anerkendt $\mathrm{i}$ en politisk frem for en videnskabelig offentlighed. Tænketanke er heller ikke interesseorganisationer, der er blevet defineret som: "... sammenslutninger af medlemmer eller andre støtter, der arbejder for politisk indflydelse" (Grant et al, 2004. I: Binderkrantz et al. 2014, 19). Det skyldes for det første, at tænketanke ikke nødvendigvis har medlemmer. Selvom nogle tænketanke giver borgere mulighed for at deltage $\mathrm{i}$ organisationens arbejde, jf. fx tænketanken Concitos "klimaambassadører", Cepos' "Akademi” eller Mandag Morgens "MM Academy”, så findes der også tænketanke som ikke gør, fx AE-rådet eller offentligt finansierede tænketanke som Det Nationale Center for Velfærd (SFI) eller Dansk Institut for International Studier (DIIS).

Endelig udfører tænketanke i modsætning til fx konsulentfirmaer ikke konkrete analyser på bestilling, fordi det sætter spørgsmålstegn ved deres uafhængighed. Samlet set er tænketanke altså organisationer, der kombinerer uafhængighed og ekspertise til at øve politisk indflydelse ofte igennem offentliggørelse af deres analyser i medierne. Tænketanke er samtidig en organisationsform, der har ændret og tilpasset sig skiftende samfundsmæssige og politiske dagsordener over tid og udbredt sig fra USA til resten af verden. 


\section{Tænketankes amerikanske rødder}

Tænketanksbegrebet blev gradvist udbredt i den offentlige diskurs i USA fra 1960erne bl.a. ud fra behovet for at inddæmme truslen fra Sovjetunionen og for at opbygge et nationalt sundhedsvæsen (Kelstrup, 2007) og på baggrund af en tiltro til, at videnskabelige fremskridt kunne bidrage til at løse strategiske samfundsudfordringer (Medvetz, 2012). Troen på tænketankes potentialer til at udfordre bureaukratisk vantetænkning blev stærk etableret i amerikansk politologi efter Anden Verdenskrig. Et centralt element var politologen Harold Lasswell's forestilling om en 'policy scientist for democracy', altså en samfundsvidenskabelig videnskabsmand, der stillede sit intellekt i demokratiets tjeneste (Lasswell, 1971, 27ff). Troen på tænketankes demokratiske potentiale var i denne periode stærk. Aaron Wildavsky brugte de amerikanske tænketanke som spydspids til at kritisere fraværet af uafhængig policy-rådgivning i Europa:

"It is exactly the intolerance for independent advice that has inhibited schools of public policy from starting in Europe. If you have hierarchical societies, if you have legitimated the idea of a bureaucracy having a monopoly over expertise in policy areas, you will not look too favourably on the idea of think tanks" (Wildavsky, 1979, xxvii).

Wildavsky's kritik ramte plet for så vidt, at private tænketanke i 1970erne ikke spillede nogen rolle i dansk politik. I Danmark var policy-viden bl.a. informeret af de offentligt støttede sektorforskningsinstitutter som fx Socialforskningsinstituttet (SFI), der i 1962 blev oprettet til at rådgive den voksende velfærdsstat på socialområdet. Desuden bidrog det korporative system til at rådgivning, inddragelse og implementering blev foretaget $\mathrm{i}$ et samspil med interesseorganisationer, som på nogle områder også overtog implementeringen af lovgivning og aftaler (Christiansen \& Nørgaard, 2003). Interesseorganisationers repræsentation af forskellige grupper var i forlængelse heraf med til at sikre, at de blev legitime og udbredte civilsamfundsaktører i Danmark (Binderkrantz et al, 2014, 13; Fisker, 2015, 46). Selvom den amerikanske model også havde stærk offentlig finansiering på fx forsvars- og sundhedsområderne, bar den danske institutionalisering af anvendt forskning præg af langt stærkere offentlig styring end i den amerikanske kontekst, som tænketanke udsprang af. 


\section{Kritikken af advocacy-tænketanke i USA}

Selvom Aaron Wildavsky priste tænketankenes uafhængige ekspertrolle, blev der allerede fra starten af 1970erne, måske som et resultat af en svækkelse af offentlige bevillinger og af troen på videnskabens evne til at løse centrale samfundsproblemer, oprettet flere, mindre og mere ideologisk farvede tænketanke i USA. De førte bl.a. kampagne for politikere eller understøttede ideologiske dagsordener (Abelson, 2006). Fremvæksten af privatfinansierede tænketanke i USA skyldes også muligheden for at modtage skattefri støtte fra private donorer under amerikansk lovgivning (§ 501 (c) i 'The Internal Revenue Code') (Rich, 2004). Udviklingen af mindre og mere ideologiske tænketanke medførte et stigende fokus på tænketankes rolle som advocacy-organisationer, der strategisk er gearet til at agitere offentligt for bestemte politiske standpunkter. Mest ikonisk udgav den konservative amerikanske tænketank The Heritage Foundation i begyndelsen af Ronald Reagans præsidentperiode i 1981 første version af 'Mandate for Leadership' - en bog med omkring 2000 forslag til konservativ politik, hvoraf mange blev implementeret (Edwards, 1997). Væksten i privatfinansierede advocacy-tænketanke i USA fortsatte og gav fra 1990erne anledning til stigende kritik fra flere sider. For det første begyndte amerikanske grundbøger i politisk interessevaretagelse, pga. tænketankenes mere advokerende rolle i politik, at forstå dem som en ny type interesseorganisation (Berry, 1997; Cigler \& Loomis, 1998; Rich, 2004, 10). For det andet blev forestillingen om et skarpt skel imellem uafhængig ekspertise og værdibaseret politik at blive udsat for kritik:

\footnotetext{
"The firewall is gone, and the change in the role and behavior of experts in recent decades suggests need for a fundamental revision in how scholars treat them in accounts of policy making" (Rich, 2004, 209).
}

I forlængelse af denne kritik udtrykte forskeren James McGann, der ellers havde markeret sig som tilhænger af tænketankes bidrag til demokratiet, bekymring for at sund konkurrence imellem tænketanke, fordi den stigende polarisering i amerikansk politik var ved at blive til en uciviliseret idékrig (McGann, 2005). Nyere forskning i tænketanke har understøttet denne bekymring ved at pege på, at tænketanke i flere tilfælde bruges som legitimering af allerede etablerede interesser i det politiske system, og at de altså ikke blot kan fungere som interessevaretagere, men også som ekspertgrundlag for holdninger, der allerede deles af politiske eliter (Medvetz, 2012, 179; Parmar, 2013; Stone, 2004, 14). 
Den ovenstående kritik af tænketanke udfordrer forestillingen om, at tænketanke løser forhåndsdefinerede samfundsproblemer. Kritikerne påpeger, at tænketanke i højere grad bidrager til at opretholde og udvikle eksisterende interesser og idéer i politik ved at give dem evidensbaseret opbakning i den offentlige debat. Denne kritik udfordrer dog ikke, at offentligheden kan bruges som en markedsplads for idéer. Selvom efterspørgslen af tænketankes idéer kan være forhåndsdefineret, kan denne efterspørgsel forstås som en ramme, der udfyldes af tænketanke. Det sker fx når politiske partier efterspørger nye forslag til at udvikle deres politik på en måde, der vil stille dem fordelagtigt i den offentlige debat. For tænketanke, der som nævnt i definitionen ovenfor må hævde uafhængighed fra etablerede interesser, er det ikke legitimt at foretage vedvarende idéudveksling direkte med bestemte beslutningstagere. Det sætter nemlig spørgsmålstegn ved, om tænketanke spiller en kritisk og demokratiserende rolle som alternativer til staten, sådan som Wildavsky forestillede sig det i 1979. I modsætning til direkte interessevaretagelse giver medierne mulighed for at foretage en offentlig og indirekte idéudveksling. Det må forventes at gøre landsdækkende dagblade til velegnede arenaer for tænketanke, idet både tænketankes stakeholders og målgrupper har en gensidig interesse i få deres idéer anerkendt $\mathrm{i}$ den offentlige debat for derved at gøre dem mere genkendelige og legitime for politiske aktører. Fremvæksten af tænketanke forventes på den baggrund at give sig til udtryk i en styrket evne til at skabe opmærksomhed omkring idéer i den offentlige debat. Forventningen om at danske tænketanke har fået øget synlighed i landsdækkende dagblade undersøges nedenfor for perioden 2006-2015. Desuden undersøges variationen i forskellige tænketankes synlighed i dagbladene i samme periode.

\section{2. Øget synlighed for tænketanke i dagbladene?}

Selvom tænketankes betydning i dansk politik endnu ikke er fyldigt belyst, er der enighed om, at der specielt efter oprettelsen af den borgerligt-liberale tænketank Cepos i 2004 er kommet flere tænketanke i Danmark (Kelstrup, 2014; McGann et al., 2014). Det kan forekomme paradoksalt og anakronistisk, at tænketanksbegrebet begyndte at fænge an i Danmark netop i samme periode som kritikken af tænketankes rolle i USA tog til og efter at den globale vækst i antallet af nye tænketanke faldt (McGann et al., 2013, 17). For bedre at kunne forklare fremvæksten af tænketankes rolle i Danmark, tester dette afsnit om tænketanke, som forventet, har opnået øget synlighed i dagbladene. 


\section{Mere synlige tænketanke i dagbladene i perioden 2006-2015}

Det bør nævnes, at uenigheden om hvordan tænketanke skal defineres, betyder, at der er usikkerhed om, hvor mange tænketanke der eksisterer generelt og i Danmark. Fx angiver en amerikansk rangering, at der var 34 tænketanke i Danmark i 2014 (McGann, 2015, 55). Frem for at opgøre hele populationen af danske tænketanke, er hensigten her at give et overblik over udviklingen i de mest medieaktive tænketanke med henblik på at sammenligne dem med de mest medieaktive interesseorganisationer. Dermed kan det illustreres, hvor meget tænketanke fylder og hvordan dagbladenes referencer til dem har udviklet sig i sammenligning med en gruppe af organisationer, der historisk har været indflydelsesrig i dansk politik. Nedenfor sammenlignes de ti hyppigst refererede tænketanke med en gruppe på ti interesseorganisationer, der er blevet identificeret som 'sværvægtere' (Binderkrantz et al, 2014). Metodisk er de mest aktive tænketanke identificeret ved at søge på en større gruppe tænketankes navne i Infomedia i ni landsdækkende dagblade i perioden fra 1. januar 2006 til 31. december 2015. De ti tænketanke med det højeste antal samlede referencer i perioden er inkluderet i figur 1 nedenfor. Tænketanke der tidligt eller sent i perioden har været hyppigt refererede, men hvis synlighed enten er ophørt eller påbegyndt sent i perioden, fremgår således ikke nødvendigvis af figuren.

Figur 1: Udviklingen $i$ summen af referencer $i$ landsdækkende dagblade til de ti mest nævnte interesseorganisationer og tænketanke fra 1. januar 2006-31.december 2015.

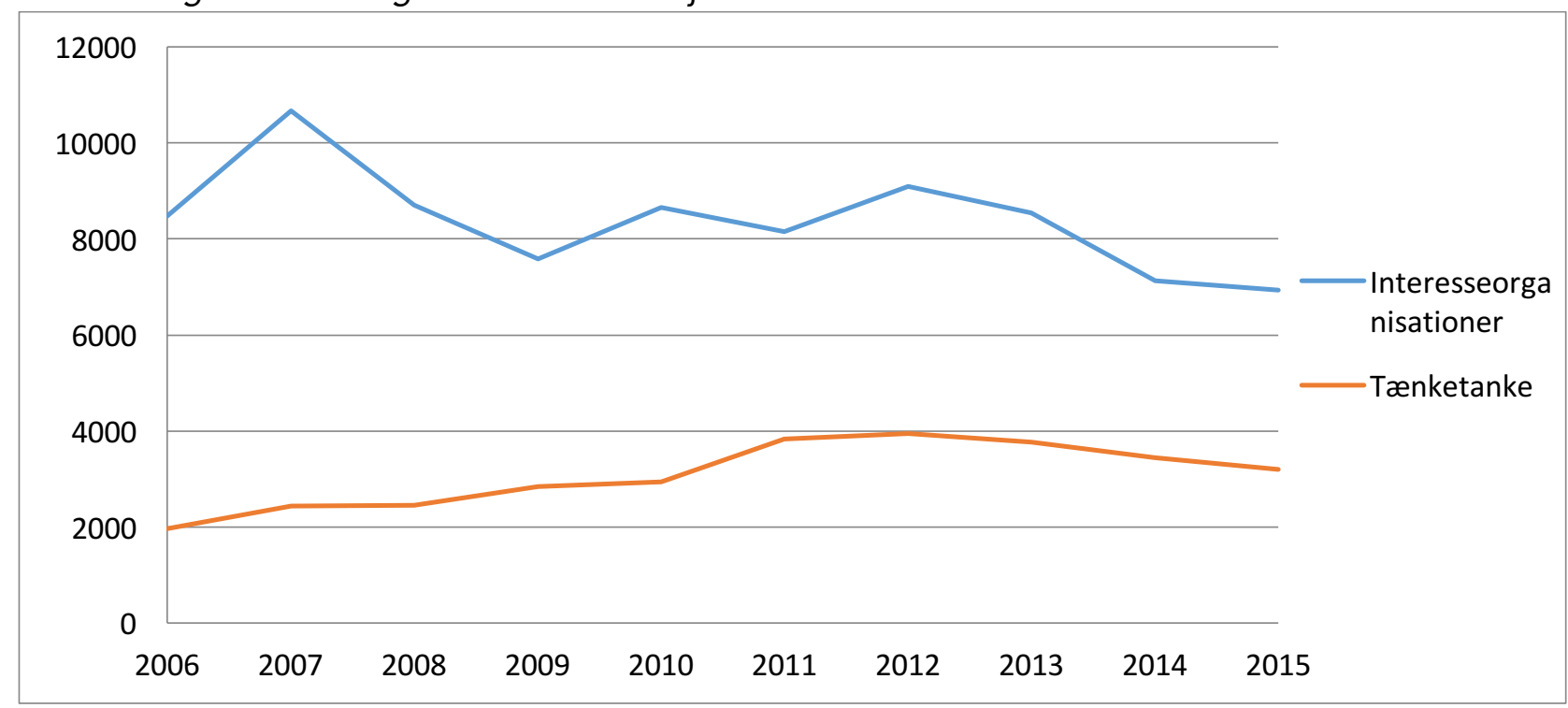

Mens der ikke har været nogen signifikant ændring $i$ antallet af referencer til interesseorganisationerne over perioden, er udviklingen i referencerne til tænketankene udtryk for en 
signifikant stigning $(\mathrm{P}<0,001) \mathrm{i}$ antallet af gange top-ti tænketankene optræder $\mathrm{i}$ dagbladene. I perioden 1. januar 2006 til 31. december 2010 repræsenterede tænketanke i gennemsnit 22,4 \% af det samlede antal citationer for de to grupper. I perioden 1. januar 2011 til 31. december 2015 var samme gennemsnit 31,4 \%. I perioden 2006 til 2015 er tænketanke altså ikke alene blevet refereret hyppigere i de landsdækkende dagblade; de har også i stigende grad kunnet konkurrere med sværvægterne iblandt danske interesseorganisationer. Fra 2012-2015 er der dog sket et mindre fald i antallet af referencer til både interesseorganisationer og tænketanke.

\section{Tænketankes uafhængighed som en komparativ fordel i dagbladene}

Hvorfor har de mest medieaktive tænketanke i de sidste ti år haft en komparativ fremgang sammenlignet med indflydelsesrige interesseorganisationer? Som indikeret ovenfor har interesseorganisationer en udbredt og legitim position i dansk politik, bl.a. fordi de historisk har varetaget en væsentlig del af den løbende folkelige repræsentation og været med til at forhandle og implementere politik (Binderkrantz et al, 2014; Christiansen \& Nørgaard, 2003). Det er derfor bemærkelsesværdigt, at tænketanke er blevet mere refereret af de landsdækkende dagblade igennem perioden. Forestillingen om at medierne fungerer som et marked for politiske idéer, kan bruges til at forstå tænketankes fremvækst i forhold til udbud og efterspørgsel af deres idéer. Et sådant perspektiv betyder, at tænketankes synlighed kan studeres ud fra færre dynamikker end de, der er knyttet til forandringer i teknologi, finansiering, lovgrundlag, politiske institutioner og uddannet arbejdskraft, som tidligere har været set som vigtige baggrundsfaktorer for deres udvikling (McGann \& Weaver, 2000, 13ff).

På udbudssiden tager markedsforestillingen udgangspunkt i, at politiske beslutninger er stabile. Det reflekterer en vigtig pointe i litteraturen om agenda-setting, nemlig at nye idéer eller policy-forslag møder modstand fra etablerede aktører, men at disse idéer alligevel, hvis de får fortsat opmærksomhed, kan få pludselig og uventet effekt (Kingdon, 2003). Interesseorganisationer kan i dette perspektiv blive underlagt det dilemma, at de enten kan vælge at blive en del af stabile beslutninger og dermed blive systembevarende, eller at de må stille sig uden for indflydelse i de perioder, hvor det politiske system ikke er lydhør overfor deres interesser (Jones \& Baumgartner, 1993). Tænketanke kan imidlertid indtage friere positioner i den politiske offentlighed, både fordi de ikke er medlemsbaserede og fordi de ikke er underlagt krav om kortsigtet indflydelse. Martin Ågerup, 
der er direktør for Cepos, fremhæver i et interview i 2011 betydningen af ikke at skulle tænke strategisk hverken i forhold til vælgere eller politikere (Ågerup, 2011, [05:58]). Cepos’ idéer bliver ifølge Ågerup ikke forhandlet til indflydelse. Derimod er brugen af idéerne afhængig af at de over tid er på mediernes dagsorden.

"Vi forventer ikke, at vores idéer bliver brugt ved gradvis overtalelse. Der opstår en situation, hvor der skal handles. Og hvis der så ligger en idé derude, som er blevet luftet, og som ikke er blevet skudt ned, så kan den anvendes. Det er sådan det ofte sker. Det kommer pludseligt, at politikere tager idéer til sig” (Ågerup, 2011: [23:11]).

Pressechefen Janus Brecht fra Arbejdsbevægelsens Erhvervsråd (AE-Rådet) fremhævede ligeledes i et interview i 2011 det langsigtede perspektiv, som AE-Rådet arbejder med, herunder at dagsordener skal skubbes kontinuerligt over tid. Brecht nævner fx, at AE's idé om 13 års uddannelsespligt er blevet forsøgt sat på den offentlige dagsorden i 12-15 år (Brecht, 2011, [39:05]). Disse interviewudtalelser indikerer, at både Cepos og AE-Rådet aktivt og over tid arbejder for at sætte offentlige dagsordener, hvilket kan fungere som en udbudsorienteret indikation på deres øgede synlighed i dagbladene. Tænketankene arbejder begge med flere målgrupper, der kan spænde fra den brede offentlighed over politiske meningsdannere til en snæver kreds af politiske beslutningstagere (Brecht, 2011; Ågerup, 2011). Omkring kernegruppen af politiske beslutningstagere, spiller det ind, at idéer skal kunne bruges strategisk.

I forhold til efterspørgslen af tænketankes idéer, skal regeringssøgende partier og beslutningstagere tage hensyn til det strukturelle pres på de offentlige budgetter (Strøm, 1990). Skiftende regeringer må foretage nedskæringer af de offentlige budgetter og for at bevare regeringsmagten må de udvikle strategier for ikke at blive straffet for det af vælgerne, når der er valg (Pierson, 1996). Det fører bl.a. til, at politikere er mere optaget af at undgå dårlig omtale (blame avoidance) end at tage æren for deres politik, fordi vælgerne er mere sensitive overfor negative end positive forandringer (Weaver, 1986). I sparetider er forhandlingsløsninger med interesseorganisationer ikke altid attraktive, fordi det er sandsynligt, at organisationers medlemmerne vil udtrykke deres utilfredshed offentligt. Mens denne dynamik er svært undgåelig fx i forbindelse med overenskomstforhandlinger imellem offentlige arbejdsgivere og faglige organisationer, kan den minimeres på andre områder ved at nedtone involveringen af interesseorganisationer i reformer. Tænketanke har den fordel at de via analyser i medierne indirekte kan imødekomme behovet for nye idéer i situationer, hvor regeringer 
skal gennemføre upopulære reformer. Mens partiernes efterspørgsel efter idéer ikke påvirker tænketankes plads i medierne direkte, kan politikere indirekte påvirke tænketankes synlighed, ved at omtale dem som relevante aktører eller ved at henvise til deres idéer. Det gør det mere sandsynligt, at journalister ser tænketanke som politiske relevante aktører og refererer til dem og deres analyser. Det er ligeledes sandsynligt, at kritiske aktører offentligt tager afstand fra tænketankenes idéer og den reformdagsorden, de relaterer sig til, hvilket forstærker tænketankenes synlighed i medierne. På den måde kan beslutningstageres og politiske partiers behov for nye idéer bidrage til at flytte politiske debatter fra lukkede forhandlingssituationer og ud i det offentlige rum og skabe øget relevans for de tænketanke, hvis idéer betragtes som politisk relevante. På den baggrund kan tænketanke bruge medierne og specielt dagbladene til at lancere deres idéer. Tænketanke har på dette idémarked den fordel, at deres idéer ikke repræsenterer medlemsinteresser, men ofte betragtes som uafhængige og som om de ikke kommer noget sted fra (Shaw et al, 2015). Derfor er tænketanke ikke bundet op på et institutionaliseret forhandlingsforhold og deres idéer kan anvendes fleksibelt. Nedenfor uddybes det, hvordan referencer til forskellige tænketanke har udviklet sig i de landsdækkende dagblade med henblik på at indikere forskellige tænketankes synlighed.

Den varierede udvikling i tænketankes synlighed i dagbladene

Udviklingen af de ti mest citerede tænketanke i perioden 2006-2015 er illustreret i figur 2 nedenfor.

Figur 2: Udvikling i referencer i landsdækkende dagblade for de ti mest nævnte tænketanke fra 1. januar 2006-31.december 2015.

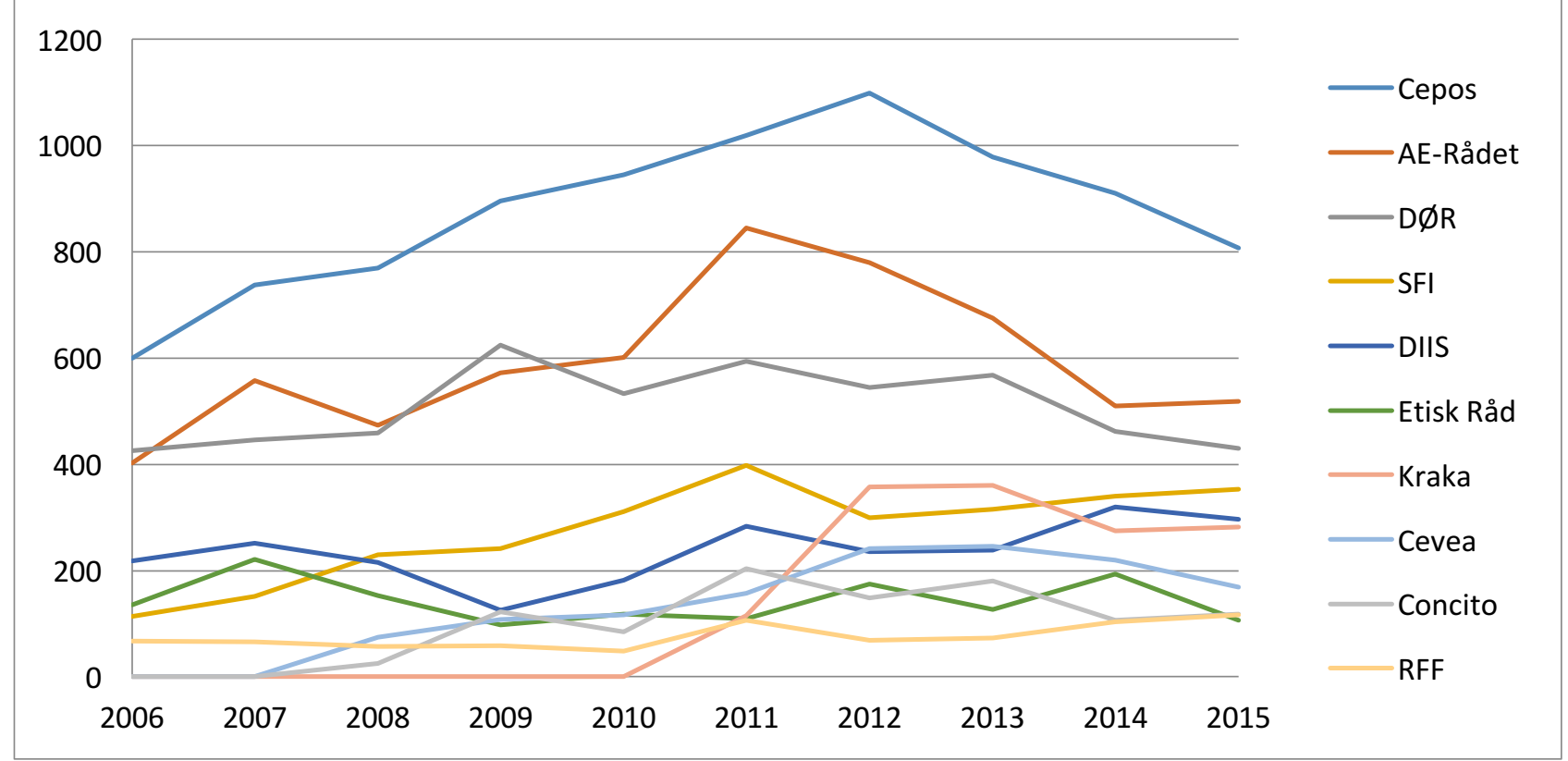


Figuren viser variation i tænketankes synlighed. Cepos og AE-Rådet har gennemgående været de mest refererede tænketanke i dagbladene i perioden. Den udbredte synlighed af disse to tænketanke i dagbladenes dækning er interessant, fordi begge tænketanke i offentligheden er kendt som hhv. en liberal og en centrum-venstre tænketank. Den relativt høje synlighed af disse tænketanke peger i samme retning som den tendens i USA, der blev refereret og kritiseret ovenfor. Også i Danmark ser det ud til, at tænketanke der har et let identificerbart politisk budskab har bedre adgang til dagbladene end andre tænketanke, som beskæftiger sig med mere afgrænsede issues som fx SFI, DIIS, klima- og miljøpolitik (Concito), erhvervs- og uddannelsespolitik (Dea), dansk europapolitik (Tænketanken Europa) eller vækst og innovation (Kraka). Det er sandsynligt, at politisk strategisk relevans er en af faktorerne i fremvæksten af Cepos og AE-rådet i dagbladene efter 2006. Et amerikansk studie har i tråd med denne forklaring fundet, at tænketanke i USA også har fået en stærkere position i takt med, at øget politisk polarisering har øget efterspørgslen efter politisk relevant viden i den amerikanske kongres (Bertelli \& Wenger, 2009). Dog har De Økonomiske Råd også en forholdsvis synlig placering i dagbladene, hvilket indikerer, at offentlige og mere konsensussøgende tænketanke også kan opnå synlighed i det omfang deres analyser betragtes som nyhedsværdige af dagbladene.

Figur 2 og den generelle udvikling af nye tænketanke, indikerer udviklinger i danske tænketankes rolle, som kræver mere præcise undersøgelser (se artiklen af Blach-Ørsten \& Kristensen i dette nummer). Som det fremgår af figuren, er der i perioden 2006-2015 oprettet flere nye tænketanke inklusive Cevea (2008), Concito (2008) og Kraka (2011), der alle haft succes med at etablere sig i top ti af tænketanke med højest antal referencer i dagbladene i løbet af perioden uden dog at komme helt op i toppen. Der bliver altså gradvist udbudt mere ekspertviden fra flere forskellige tænketanke over perioden. Det øgede antal tænketanke og den øgede konkurrence om synlighed i medierne kan være medvirkende til at forklare det generelle fald i omtalen for organisationerne efter 2012. Ligesom en aftagende interesse for tænketanke som nyt fænomen også kan spille en rolle.

Det er vigtigt at undersøge mere præcist, hvad den øgede konkurrence om adgang til offentlig synlighed betyder, for at uddybe den forestilling om tænketankes brug af medierne, der blev skitseret ovenfor. Ligeledes har de fleste tænketanke ved siden af deres medierettede strategier, direkte relationer til politikere og andre stakeholders. Medieeksponering er altså ikke det eneste succeskriterium for tænketanke. Eksempelvis har Martin Ågerup fra Cepos i 2015 indikeret, at tænketanken er begyndt at prioritere alternative kanaler til indflydelse højere end medieadgang (Løppenthin, 2015). Men hvordan påvirker tænketankes prioritering imellem direkte og indirekte 
indflydelse deres synlighed i medierne? Har etablerede tænketanke spill-over fra den ene kanal til den anden, ligesom det er blevet indikeret for interesseorganisationer (Binderkrantz et al, 2014)?

I forhold til efterspørgslen efter tænketankes idéer, tyder Cepos og AE-rådets høje grad af synlighed på, at dagbladene vægter tænketankes politiske relevans og aktualitet højt. Men hvordan hænger individuelle tænketankes relevans for medierne sammen med efterspørgslen af deres viden på Christiansborg?

Forestillingen om udviklingen af et marked for udveksling af idéer har peget på, at tænketanke er vokset frem i Danmark pga. af øget efterspørgsel efter politiske relevante idéer igennem medierne. Samtidig stiller forestillingen nye spørgsmål omkring udviklingen og indholdet i tænketankes analyser, den politiske efterspørgsel efter deres idéer og konsekvenserne af flere tænketanke i dansk politik. Hertil er der også behov for at svare på mere grundlæggende spørgsmål om tænketanke, herunder om deres analyser fungerer som alternativer til den ekspertise, der findes i den offentlige administration, sådan som Aaron Wildavsky forestillede sig det.

\section{Konklusion}

Artiklen har påvist, at tænketanke er blevet mere synlige i landsdækkende danske dagblade i perioden 2006-2015. Der er desuden blevet argumenteret for, at udviklingen i danske tænketankes medieadgang i de dagsordenssættende dagblade overordnet kan forstås ud fra deres evne til at bruge dagbladene som et marked for udveksling af politiske idéer. En sådan forestilling åbner vigtige overvejelser omkring tænketankes udbud og efterspørgsel af evidensbaseret viden i den offentlige debat. Artiklen har dermed både bidraget med en påvisning af tænketankes øgede synlighed $\mathrm{i}$ dagbladene og med en forestilling om, hvordan de bruger medierne til at opnå synlighed i den danske offentlighed.

Mere præcist har artiklen for det første argumenteret for, at tænketanke analytisk kan defineres som "permanente organisationer, der hævder en grad af uafhængighed og søger politisk indflydelse ved at mobilisere ekspertviden” (Kelstrup, 2014, 21). Der er ud fra tænketankes amerikanske rødder blevet argumenteret for, at de er i konkurrence med interesseorganisationer, men på basis af ekspertviden frem for medlemsbaseret legitimitet. For det andet er der blevet givet et billede af det relative styrkeforhold imellem gruppen af de mest citerede tænketanke og interesseorganisationer i de seneste 10 år. Det er blevet vist, at de ti største tænketanke i perioden 2006-2015 har oplevet en signifikant 
stigning i det antal gange, de bliver citeret i landsdækkende dagblade. I forhold til konkurrencen med sværvægterne blandt interesseorganisationerne har stigningen betydet, at tænketankes andel af de to gruppers mediecitationer er steget fra et gennemsnit på 22,4 \% af det samlede antal citationer for de to grupper i perioden 2006-2010 til et gennemsnit på 31,4 \% i perioden 2010-2015. Tænketanke bruger dagblade til at få anerkendt deres analyser offentligt, fordi de både ud fra teorien om agendasetting og udvalgte tænketankspraktikeres udsagn har en interesse i at udbyde ekspertbaseret viden $\mathrm{i}$ medierne. Tænketankes idéer efterspørges af beslutningstagere der, jf. teorien om blame avoidance, efterspørger evidensbaseret viden, som kan anvendes uden at der skal forhandles med udbyderne af denne viden. Artiklen har vist, at tænketankene Cepos og AE-rådet, som leverer viden ud fra tydelige idépolitiske ståsteder, i perioden 2006-2015 har været mere refererede i dagbladene end andre tænketanke. Fremtiden for danske tænketanke er nu endnu mere interessant at undersøge, end den var for blot et par år siden. Ændringer i form af øget konkurrence imellem et større antal tænketanke, forholdet imellem direkte og indirekte strategier og variationer i den politiske efterspørgsel er vigtige temaer for den fremadrettede forskning i tænketanke, der forhåbentligt kan gøre os klogere på årsager til og konsekvenser af tænketankes rolle i danske medier og politik.

\section{Litteratur}

Abelson, D. E. (2006) A capitol idea: think tanks and US foreign policy. Canada: McGill-Queen's University Press.

Arnoldi, J. (2005) Den offentlige ekspert. Frederiksberg: Samfundslitteratur.

Berry, J. M. (1997) The Interest Group Society, 3rd edition. New York: Longman.

Bertelli, A. M. \& Wenger, J. B. (2009) Demanding Information: Think Tanks and the US Congress. British Journal of Political Science, 39(02), 225-242.

Binderkrantz, A. S., Christiansen, P. M. \& Pedersen, H. H. (2014) Organisationer i politik. Danske interesseorganisationer i forvaltning, Folketing og medier. Hans Reitzels Forlag.

Brecht, J. (2011) Interview 22. marts.

Christiansen, P. M. \& Nørgaard, A. S. (2003) Faste Forhold - Flygtige Forbindelser. Stat og interesseorganisationer i Danmark i det 20. århundrede. Gylling: Aarhus Universitetsforlag.

Cigler, A. J. \& Loomis, B. A. (eds) (1998) Interest Group Politics, 5th edition. Washington D.C.: CQ Press.

Dickson, P. (1972) Think tanks. New York: Ballatine. 
Edwards, L. (1997) The Power of Ideas: The Heritage Foundation at 25 Years. Jameson Books.

Fisker, H. M. (2015) Gamle venner og nye bekendtskaber: udvikling i den danske interessegruppepopulation. Politica, 47(1), 46-65.

Grant, J., Halpin, D. \& Maloney, W. (2004) Defining Interests: Disambiguation and the need for new distinctions. British Journal of Politics and International Relations, 6(2), 195-212.

Henriksen, T. B. (2014) Tænketanke og professorer tryner lobbyister, Børsen. 29.12.14 2014. Available online: http://borsen.dk/nyheder/avisen/artikel/11/101448/artikel.html.

Jones, B. D. \& Baumgartner, F. R. (1993) Agendas and Instability in American Politics. Chicago, United States: University of Chicago Press.

Kelstrup, J. D. (2007) Tænketanke i forandring - imellem national sikkerhed og globalt risikosamfund. Militcert Tidsskrift, 136(2), 131-142.

Kelstrup, J. D. (2014) Think Tanks in Europe: Explaining their Development and Variation in Germany, the United Kingdom, Denmark and at the EU-level. PhD Roskilde University.

Kingdon, J. W. (2003) Agendas, Alternatives and Public Policies, 2nd edition. United States: Addison-Wesley Educational Publishers Inc.

Lasswell, H. D. (1971) A Pre-view of Policy Sciences. New York, United States: American Elsevier Publishing.

Løppenthin, R. (2015) Taenketanke får mindre taletid $i$ medierne, 2015. Available online: $\mathrm{http} / /$ www.altinget.dk/artikel/taenketanke-faar-mindre-taletid-i-medierne.

McGann et al. (2014) Global Go-To Think Tank Index Report 2013. Think tank and Civil Societies Program. University of Pennsylvania.

McGann et al., J. (2013) Global Go-To Think Tanks Index Report 2012. Think tank and Civil Societies Program

McGann, J. (2005) US think-tanks: casualties in the war of ideas, 2005. Available online: http://www.opendemocracy.net/democracy-think_tank/us_thinktanks_3137.jsp.

McGann, J. G. (2015) 2014 Global Go To Think Tank Index Report.

McGann, J. G. \& Weaver, R. K. (eds) (2000) Think tanks and civil societies: catalysts for ideas and action. New Brunswick, NJ: Transaction Publishers.

Medvetz, T. (2012) Think Tanks in America. University of Chicago Press.

Parmar, I. (2013) The knowledge politics of democratic peace theory. International Politics, 50, 231256.

Pierson, P. (1996) The New Politics of the Welfare State. World Politics, 48(2), 143-179. 
Rich, A. (2004) Think tanks, public policy, and the politics of expertise. Cambridge, UK New York: Cambridge University Press.

Sartori, G. (1970) Concept Misformation in Comparative Politics. The American Political Science Review, 64(4), 1033-1053.

Shaw, S. E., Russell, J., Parsons, W. \& Greenhalgh, T. (2015) The view from nowhere? How think tanks work to shape health policy. Critical Policy Studies, 9(1), 58-77.

Stone, D. (2004) Introduction: think tanks, policy advise and governance., in Stone, D. \& Denham, A. (eds), Think tank traditions - policy research and the politics of ideas. Manchester: Manchester University Press.

Strøm, K. (1990) A Behavioral Theory of Competitive Political Parties. American Journal of Political Science, 34(2), 565-598.

Weaver, K. R. (1986) The Politics of Blame Avoidance. Journal of Public Policy, 6(5), 371-398.

Wildavsky, A. B. (1979) Speaking Truth to Power: The Art and Craft of Policy Analysis. Boston: Little-Brown.

Ågerup, M. (2011) Interview 6. Maj. 